DOI: http://dx.doi.org/10.25181/jofsa.v2i1.1054

Journal of Food System and Agribusiness Vol. 2 (1): 55-67

\title{
POTENSI KEHILANGAN HASIL PANEN DAN PASCA PANEN JAGUNG DI KABUPATEN LAMPUNG SELATAN
}

\author{
POTENTIAL LOSS OF MAIZE HARVEST AND POST HARVEST \\ IN SOUTH LAMPUNG DISTRICT \\ Valeriana Darwis ${ }^{1)}$ \\ ${ }^{1)}$ Pusat Sosial Ekonomi dan Kebijakan Pertanian \\ E-mail : valicfurca@gmail.com
}

\begin{abstract}
Poor harvest and post harvest handling can reduce corn production in terms of quantity and quality. Therefore, this paper aims to know the potential loss of maize crops and post-harvest through the habits of farming cultivation in South Lampung, especially during the activities of harvesting, shelling, drying and storing. The results of the study showed that corn farmers understand the importance of harvest and post harvest handling in producing quality corn production. However, not all farmers put their understanding into practice even if the technology for harvesting and post-harvest activities have been invented and implemented by the ministry of agriculture. In order to increase the income of corn farmers, the socialization and demonstration of the use of the tools or technology specific to harvest and post harvest location needs to be enhanced.
\end{abstract}

Keywords: loss, harvest, post harvest and corn

Disubmit :30 April 2018 Diterima:30 Maret 2018, Disetujui :1 April 2018

\section{PENDAHULUAN}

Panen dan pasca panen merupakan kegiatan yang dapat menentukan kualitas dan kuantitas produksi. Kesalahan dalam penanganan panen dan pasca panen dapat mengakibatkan kerugian yang sangat besar. Oleh karena itu penanganan panen dan pasca panen secara benar perlu mendapat prioritas dalam proses produksi usahatani. Ketahanan pangan sangat diperlukan oleh suatu bangsa (Fitriani, 2017), salah satu tanaman pangan yang sangat penting ialah jagung. Menurut Suma (2008), produksi jagung dalam negeri banyak yang tidak diserap oleh pabrik pakan karena kualitasnya rendah, seperti kadar air tinggi, banyak butiran rusak, warna tidak seragam, dan kandungan kotoran melampaui batas toleransi. Hal ini terjadi karena penanganan pascapanen jagung kurang mendapat perhatian. Untuk menghasilkan jagung yang berkualitas baik sehingga berdaya saing, perlu penanganan pascapanen yang tepat. Sesuai dengan persyaratan mutu yang diminta oleh sektor industri, Bulog membuat persyaratan mutu jagung pipilan kering, yakni kadar

Darwis (Potensi Kehilangan Hasil Panen dan Pasca Panen Jagung Di Kabupaten Lampung Selatan) 
DOI: http://dx.doi.org/10.25181/jofsa.v2i1.1054

Journal of Food System and Agribusiness Vol. 2 (1): 55-67

air 14\%, kadar kotoran 3\%, kadar butir rusak 5\%, kadar butir warna lain 10\%, kadar butir pecah 0\%, dan bebas dari hama dan bau apek (Isnawati 2011).

Kegiatan pascapanen hasil pertanian dapat dikelompokkan menjadi dua tahapan utama, yaitu pasca panen primer (penanganan) dan pasca panen sekunder (pengolahan). Teknologi pasca panen primer maupun sekunder berperan penting dalam menciptakan nilai tambah komoditas pertanian melalui proses agroindustri. Kegiatan pasca panen primer meliputi pemungutan (panen), perontokan/pemipilan, pengeringan, sortasi, pengemasan, pengangkutan, dan penyimpanan. Tujuannya adalah untuk menurunkan kehilangan hasil, menekan tingkat kerusakan, dan meningkatkan daya simpan dan daya guna komoditas untuk memperoleh nilai tambah (Setyono et al. 2008). Penanganan pascapanen yang tidak baik akan menyebabkan kehilangan hasil, baik bobot maupun kualitas produk yang dihasilkan, terutama untuk panen pada musim hujan (Firmansyah et al. 2007).

Menurut Direktorat Jenderal Pengolahan dan Pemasaran Hasil Pertanian, penanganan pascapanen yang kurang baik menyebabkan kehilangan hasil jagung masih tinggi, berkisar antara 15-20\%. Bakusheva et al. (2012) mengungkapkan bahwa kehilangan hasil pada tahap pascapanen merupakan faktor utama yang berpengaruh negatif terhadap ketahanan pangan masyarakat di Amerika Tengah. Pemanfaatan alat pengering dan penyimpan silo selama 20 tahun (1983-2003) berdampak nyata terhadap peningkatan kesejahteraan masyarakat yang dievaluasi pada periode 2005-2009. Di wilayah Sub-Sahara Afrika, kerugian pascapanen diperkirakan mencapai 30\% per tahun. Hal ini menunjukkan bahwa penanganan pascapanen mempunyai peran penting dalam pengelolaan usaha pertanian, terutama dalam mencegah keracunan aflatoksin (Kimatu et al. 2012).

Kehilangan hasil panen produksi pada umumnya terjadi pada saat proses panen dan pasca panen. Kehilangan hasil jagung pada pascapanen dapat berupa kehilangan kuantitatif dan kualitatif. Kehilangan kuantitatif merupakan susut hasil akibat tertinggal di lapang waktu panen, tercecer saat pengangkutan, atau tidak terpipil. Kehilangan kualitatif merupakan penurunan mutu hasil akibat butir rusak, butir berkecambah, atau biji keriput selama proses pengeringan, pemipilan, pengangkutan atau penyimpanan. Dengan adanya permasalahan diatas, maka tulisan ini bertujuan ingin mengetahui potensi kehilangan hasil panen dan pasca panen jagung melalui kebiasaan budidaya petani yang ada di Lampung Selatan.

\section{METODOLOGI}

Penelitian dilakukan pada tahun 2016 dan survay ke lokasi dilaksanakan pada bulan Agustus. Pemilihan kabupaten berdasarkan hasil diskusi dengan Dinas Pertanian Provinsi dengan kriteria termasuk kabupaten sentra produksi jagung. Agar terlihat keragamannya, maka lokasi penelitian dibedakan atas penanaman jagung di lahan kering dan lahan basah. Berdasarkan kriteria tersebut lokasi yang terpilih adalah: Kecamatan Ketapang untuk jagung yang ditanam di lahan kering dan Kecamatan Penengahan untuk jagung yang ditanam di lahan sawah tadah hujan.

Darwis (Potensi Kehilangan Hasil Panen dan Pasca Panen Jagung Di Kabupaten Lampung Selatan) 
DOI: http://dx.doi.org/10.25181/jofsa.v2i1.1054

Journal of Food System and Agribusiness Vol. 2 (1): 55-67

Tulisan ini mempergunakan data primer yang diperoleh dengan cara mewawancari 20 responden petani jagung yang dipilih secara random di masing-masing lokasi. Wawancara mempergunakan pertanyaan terstruktur yang khususnya mempertanyakan kegiatan panen dan pascapanen yang penting atau tidak penting menurut responden dan beberapa dari kegiatan panen dan pasca panen tersebut yang dilakukan oleh responden. Data yang terkumpul tersebut kemudian dianalisis berdasarkan presentase dan ditampilkan dalam bentuk tabel.

\section{HASIL DAN PEMBAHASAN}

Proses pasca panen jagung terdiri atas serangkaian kegiatan yang dimulai dari pemetikan dan pengeringan tongkol, pemipilan tongkol, pengemasan biji, dan penyimpanan sebelum dijual ke pedagang pengumpul. Ke semua proses tersebut apabila tidak tertangani dengan baik akan menurunkan kualitas produk karena berubahnya warna biji akibat terinfeksi cendawan, jagung mengalami pembusukan, tercampur benda asing yang membahayakan kesehatan. Lebih lengkapnya kegiatan pasca panen dan potensi kehilangan hasil dapat dilihat pada tabel 1

Tabel 1. Kegiatan Panen, Pasca Panen dan Potensi Kehilangan hasil

\begin{tabular}{lll}
\hline No & Kegiatan & \multicolumn{1}{c}{ Aktivitas dan Potensi Kehilangan Hasil } \\
\hline 1. & Panen & $\begin{array}{l}\text { Penentuan waktu panen, pemungutan hasil, pengumpulan, } \\
\text { pengangkutan }\end{array}$
\end{tabular}

2. Pengupasan Pelepasan kulit, pemisahan jagung yang baik dan yang rusak

3. Pengeringan Angkut tongkol ke tempat pengeringan, pengeringan dan pemrosesan hasil pengeringan

4. Pemipilan Memipil tongkol, memisahkan biji dari kotoran, memproses jagung pipilan keringMemipil tongkol, memisahkan biji dari kotoran, memproses jagung pipilan kering

5. Penyimpanan Menyimpan biji dalam ruang penyimpanan untuk mempertahankan mutu

6. Pengangkutan Pengeringan biji dan pemindahan untuk proses selanjutnya

Sumber : Firmansyah, dkk (2006)

\section{PANEN DAN PASCA PANEN DI LOKASI PENELITIAN Panen}

Jagung (corn / maize) dapat dipanen untuk diambil/dimanfaatkan dalam bentuk: (1) biji jagung dan tongkolnya, dan (2) seluruh biomassa tanaman jagung yang berada di atas permukaan tanah. Jagung yang dipanen dalam bentuk biji dan tongkolnya biasanya dimanfaatkan bijinya untuk dikonsumsi oleh manusia, sedangkan jagung yang dipanen

Darwis (Potensi Kehilangan Hasil Panen dan Pasca Panen Jagung Di Kabupaten Lampung Selatan) 
DOI: http://dx.doi.org/10.25181/jofsa.v2i1.1054

Journal of Food System and Agribusiness Vol. 2 (1): 55-67

dalam bentuk biomassa jagung umumnya digunakan untuk dijadikan makanan ternak (silage, atau ensilage), terutama untuk tanaman jagung muda. Dengan menggunakan mesin panen jagung maka tongkol jagung bisa dipisahkan dari biomassa lainnya seperti batang dan daun

Pemanenan jagung dapat dilakukan dengan cara manual dan mekanis. Secara manual dapat dilakukan dengan cara memetik tongkol jagung, sedangkan biomassa selain tongkol jagung dibabat untuk dijadikan makanan ternak. Secara mekanis dilakukan dengan menggunakan mesin panen jagung (corn / maize harvester). Mesin panen jagung dapat dibedakan berdasarkan hasil akhir pemanenan. Apabila hasil akhir berupa tongkol jagung yang terpisah dengan biomassa batang dan daun dinamakan corn harvester atau corn combine harvester, sedangkan apabila hasil akhir berupa potongan-potongan kecil (cacahan) seluruh biomassa jagung dinamakan ensilage harvester. Mesin panen jagung memanen seluruh biomassa tanaman jagung yang berada di atas permukaan tanah dengan proses pemanenan jagung sebagai berikut: (a) Mengarahkan batang-batang jagung dalam suatu barisan ke dalam bagian pemotong batang jagung ; (b) Memotong batang-batang jagung ; (c) Mengangkut potongan batang-batang jagung ; (d) Memisahkan tongkol dan biomassa lainnya seperti batang dan daun ; (e) Mencacah biomassa batang dan daun ; (f) Menampung tongkol atau meletakkannya di belakang mesin di atas tanah ; (g) Mengalirkan cacahan biomassa batang dan daun jagung ke alat/kendaraan angkut di samping atau di belakang mesin.

Cara panen konvensional seperti yang sudah sering dilakukan oleh para petani jagung, yaitu dengan memotong batang tanaman, mengumpulkannya dan kemudian mengupas kulit jagung/klobot dan memetik tongkol jagung. Selanjutnya mengumpulkan jagung yang telah bersih dari kulitnya atau jagung glondong ke zak yang telah disiapkan dan selanjutnya dibawa pulang. Proses selanjutnya jagung dipisahkan dengan jenggel/dipipil dengan mesin pemimil jagung/selep jagung, setelah itu baru dijemur di bak-an/hamparan luas.

Pamanenan jagung menggunakan mesin, tahapan pemanenan diatas menjadi satu dikerjakan oleh mesin pemanen jagung, yaitu pembabatan, pengumpulan, pemisahan buah dari batang dan kulit/klobot dan kemudian masuk ke proses selep sehingga keluar sudah menjadi pipilan. Mesin pemanen jagung melakukan itu semua dengan satu langkah, bandingkan dengan cara konvensional yang membutuhkan waktu yang lama, tenaga kerja banyak, otomatis juga biaya akan banyak. Panen menggunakan mesin pemanen jagung maka dapat lebih mudah dan efisien hanya membutuhkan waktu 2 jam/hektar.

Ada 2 macam mesin pemanen jagung menurut hasil akhir dari proses panen : (i) jika hasil panen berupa jagung tongkol yang bersih dan terpisah dari klobot/kulit buah/biomassa mesin yang memanen disebut com harvester atau com combine harvster. (ii) Jika hasil panen sudah berupa cicilan jagung/klobot, batang tanaman hancur menjadi cacahan maka mesin panen disebut Ensolage hargester.

BBP Mektan telah menghasilkan berbagai teknologi mekanisasi untuk penanganan pascapanen jagung, seperti mesin pengupas jagung, mesin pemipil jagung, mesin pengering jagung dengan bahan bakar biomassa seperti sekam padi atau tongkol

Darwis (Potensi Kehilangan Hasil Panen dan Pasca Panen Jagung Di Kabupaten Lampung Selatan) 
DOI: http://dx.doi.org/10.25181/jofsa.v2i1.1054

Journal of Food System and Agribusiness Vol. 2 (1): 55-67

jagung, dan alsintan lainnya. Di antara alsintan tersebut, mesin pemipil jagung merupakan alsintan pascapanen yang paling berkembang di masyarakat.

Waktu panen menentukan mutu biji jagung. Pemanenan yang terlalu awal menyebabkan banyaknya butir muda sehingga kualitas dan daya simpan biji rendah. Sebaliknya, pemanenan yang terlambat menyebabkan penurunan kualitas dan peningkatan kehilangan hasil akibat cuaca yang tidak menguntungkan atau serangan hama dan penyakit di lapang. Hasil survei menunjukkan bahwa kadar air jagung yang dipanen pada musim hujan masih tinggi, berkisar antara 25-35\%. Apabila tidak ditangani dengan baik, jagung berpeluang terinfeksi cendawan yang menghasilkan mikotoksin jenis aflatoksin (Firmansyah et al. 2006).

Secara visual, jagung sudah siap dipanen bila : (i) batang, daun dan kelobot berubah menjadi kuning atau telah mengering, (ii) klobot kering berwarna kuning dan bila dikupas biji mengkilap, (iii) bila biji ditekan dengan kuku tidak berbekas dan (iv) terdapat bintik hitam pada bagian biji yang melekat pada tong. Faktor penentu kualitas untuk panen dikuesioner lebih difokuskan pada penentuan hari panen, melakukan pemangkasan sebelum dipetik, umur petik antara 7-10 hari setelah dipangkas dan penjemuran tongkol jagung dimulai 10 hari setelah dipetik dan dijemur selama 3 hari.

Panen sesuai umur sangat penting, karena bisa mempengaruhi produksi. Berapa produksi yang dihasilkan apabila waktunya pas dapat dilihat secara lengkap pada tabel 2 . Kebiasaan petani di Lampung Selatan beragam antara lahan sawah dan lahan kering. Seluruh responden di dua lokasi sepakat bahwa umur panen mempengaruhi produksi dan umumnya dilaksanakan oleh $90,80 \%$ petani di lahan kering dan $85 \%$ petani di lahan sawah (Tabel 3). Kegiatan pemangkasan sebelum pemetikan, pemetikan dilakukan setelah 7-10 hari dan penjemuran tongkol jagung maksimal 10 setelah pemetikan dirasakan oleh petani jagung di lahan kering bukanlah kegiatan yang penting dan petani responden yang melakukan kegiatan tersebut tidaklah banyak. Hal yang berbeda terjadi petani jagung lahan sawah, dimana kegiatan pemetikan dilakukan setelah 7-10 hari dan penjemuran tongkol jagung maksimal 10 setelah pemetikan adalah kegiatan yang penting, tetapi petani responden yang melakukannya tidaklah banyak (kurang dari 50\%).

Tabel 2. Umur Panen Potensi Hasil Dan Rata-Rata Hasil Berbagai Varietas Jagung

\begin{tabular}{cccc}
\hline Varietas & Umur & Potensi Hasil (Ton/ha) & Rata- rata Hasil (Ton/ha) \\
\hline C5 & $95-105$ & - & 8,0 \\
C6 & $98-105$ & - & $10-10,3$ \\
C7 & $95-105$ & $10-12,4$ & 8,1 \\
Pioneer 10 & $93-117$ & $10-11$ & 7,66 \\
Pioneer 11 & $96-124$ & $10-12$ & 7,66 \\
Pioneer 12 & $92-120$ & $10-12$ & 8,105 \\
Pioneer 13 & $90-115$ & $10-11$ & 8,027 \\
Pioneer 14 & $89-112$ & $10-11$ & 7,578 \\
CPI -1 & 97 & - & 6,2 \\
CPI- 2 & 97 & $8-9$ & 6,2 \\
IPB 4 & $100-105$ & - & 6,6 \\
Semar 1 & $95-100$ & $8-9$ & $5,3-6,4$ \\
\hline
\end{tabular}

Darwis (Potensi Kehilangan Hasil Panen dan Pasca Panen Jagung Di Kabupaten Lampung Selatan) 
DOI: http://dx.doi.org/10.25181/jofsa.v2i1.1054

Journal of Food System and Agribusiness Vol. 2 (1): 55-67

\begin{tabular}{cccc}
\hline Semar 2 & 91 & - & $5,0-6,1$ \\
Semar 3 & 94 & $8-9$ & 5,3 \\
\hline
\end{tabular}

Tetapi pada kegiatan pemangkasan sebelum pemetikan dianggap petani merupakan kegiatan yang tidak mempengaruhi kualitas dan petani tidak melakukannya. Kebiasan petani di lokasi penelitian adalah panen dilakukan dengan cara memotong dahan dengan mempergunakan tenaga manusia, kemudian jagung diambil dengan tongkolnya dimasukan ke dalam karung. Meskipun penting penjemuran, tetapi petani dilahan sawah tidak melakukannya. Hal ini disebabkan karena tidak ada waktu untuk mengerjakannya dan biasanya pada saat penjemuran tongkol jagung musim hujan sudah masuk. Dengan masuknya musim hujan petani lebih banyak menghabiskan waktunya manggarap lahan sawahnya untuk ditanaman padi.

\section{Pemipilan}

Pemipilan merupakan salah satu kegiatan pascapanen jagung yang tergolong kritis, karena dapat menyebabkan kehilangan hasil hingga 4\%. Pada proses pemipilan menggunakan alat, kadar air biji sangat memengaruhi kapasitas alat dan mutu hasil pipilan (butir pecah dan kadar kotoran). Disarankan melakukan pemipilan saat kadar air biji jagung berkisar antara 15-20\%. Makin tinggi kadar air jagung yang dipipil, makin rendah kapasitas pipilan serta makin tinggi persentase butir pecah dan kadar kotoran. Pemipilan menggunakan alsin pemipil buatan Balai Penelitian Tanaman Serealia (Balitsereal) pada kadar air biji 15-20\% dapat menyelamatkan jagung dari infeksi cendawan (Mulyono 2012).

Pemipilan biji jagung berpengaruh terhadap butir rusak, kotoran, dan membantu mempercepat proses pengeringan. Proses pemipilan akan berlangsung dengan mudah dan kualitas pipilan tinggi apabila tanaman sudah mencapai umur panen yang ditentukan dan kadar air biji pada saat panen rendah $(<18 \%)$. Seperti kegiatan pengeringan, pemipilan jagung dapat dilakukan secara manual dengan tangan atau secara mekanis dengan bantuan alat-mesin.

Pemipilan secara manual dilakukan dengan cara memipil biji satu per satu dari tongkolnya, baik dengan tangan maupun dengan bantuan alat sederhana. Pemipilan biji dengan tangan tidak akan terjadi kerusakan fisik biji meskipun pada saat pemipilan kadar air biji tinggi (>30\%). Cara pemipilan dengan tangan banyak dilakukan untuk penyediaan benih. Kerugian dari cara ini adalah memerlukan waktu yang lama dan membutuhkan banyak tenaga kerja, mencapai $9 \mathrm{HOK} / \mathrm{ha}$.

Cara lain yang banyak dilakukan petani untuk memipil jagung pada saat kadar air biji masih tinggi adalah dengan memasukkan jagung ke dalam kantung, kemudian didiamkan selama 24 jam, lalu jagung yang masih berada di dalam kantung tersebut dipukul-pukul. Cara pemipilan dengan bantuan alat sederhana ini menyebabkan banyak biji yang rusak, terutama pada saat kadar air biji masih tinggi.

Pemipilan dengan alat sederhana yang lain adalah menggunakan alat gosok berupa papan kayu yang dipasangi paku sebagai alat pencongkel biji jagung agar terlepas

Darwis (Potensi Kehilangan Hasil Panen dan Pasca Panen Jagung Di Kabupaten Lampung Selatan) 
DOI: http://dx.doi.org/10.25181/jofsa.v2i1.1054

Journal of Food System and Agribusiness Vol. 2 (1): 55-67

dari tongkolnya. Kapasitas kerja alat gosok berkisar antara 8-12,5 kg/jam/operator pada kondisi kadar air biji > 25\% dengan persentase biji rusak 6-9\%.

Alat pemipil jagung yang mudah dipindah-pindah (mobile) dengan tenaga gerak manusia (Ramapil) telah dikembangkan oleh Balitkabi. Menyerupai becak, silinder perontok biji digerakkan dengan cara mengayuh. Kapasitas kerja Ramapil 400-500 kg jagung tongkol/jam. Alat pemipil jagung rancang bangun Balitkabi terdiri atas tiga tipe, yaitu tipe F11.223 dengan tenaga penggerak putar tangan, tipe F11.223 dengan tenaga penggerak injak, dan tipe F11.223 dengan tenaga penggerak kayuh pedal. Masing-masing alat mempunyai kapasitas kerja 191,9 kg/jam/orang (laki-laki) untuk tenaga gerak putar tangan, $114,9 \mathrm{~kg} / \mathrm{jam} /$ orang (wanita) dengan tenaga gerak kayuh pedal.

Beberapa alat pemipil jagung secara mekanis mempergunakan tenaga gerak enjin atau motor listrik telah dibuat oleh bengkel alat dan mesin pertanian di pedesaan, industri lokal, lembaga penelitian, dan perguruan tinggi. Sebagian besar alat pemipil yang ada di pasar saat ini hanya cocok untuk pemipilan jagung dengan kadar air $<18 \%$. Pemipil jagung bertenaga gerak enjin yang banyak digunakan petani di Jawa Timur menunjukkan tingkat kerusakan biji 18-21\% untuk jagung dengan kadar air 32,5-35\% pada putaran silinder perontok $600 \mathrm{rpm}$. Tingkat kerusakan biji tersebut melebihi standar yang ditetapkan oleh BULOG, yaitu 3\%. Kapasitas kerja pemipil jagung bertenaga gerak enjin berkisar antara 0,8-1,2 t/jam.

Balitkabi juga telah merancang alat pemipil jagung bertenaga gerak enjin 7 HP yang diberi nama SENAPIL. Kapasitas kerja efektif SENAPIL untuk memipil jagung tongkol dengan diameter $>5,0 \mathrm{~cm}$ adalah $1,1 \mathrm{t} / \mathrm{jam}$. Untuk jagung tongkol berdiameter $<5$ $\mathrm{cm}$ dan $>25 \mathrm{~cm}$ masing-masing $1,3 \mathrm{t}$ dan $0,8 \mathrm{t} / \mathrm{jam}$. Efisiensi pemipilan SENAPIL mencapai $99,96 \%$ dengan tingkat kerusakan biji $6 \%$ pada kadar air 15,5\% basis basah (Tastra. 1996).

Balitsereal telah memodifikasi mesin pemipil model PJ-M1 yang dilengkapi dengan komponen pengayak. Komponen pengayak tersebut dimaksudkan untuk memisahkan biji jagung dengan serpihan tongkol. Hasil pengujian menunjukkan bahwa biji jagung yang dipipil dengan PJ-M1 telah memenuhi persyaratan SNI pada kadar air biji $15 \%$ saat pemipilan. Biaya pemipilan dengan mesin pemipil model PJ-M1 lebih murah (Rp 25/kg) dibanding mesin pemipil yang digunakan oleh umumnya petani (Rp $30 / \mathrm{kg})$.

Ditingkat petani responden cara pemipilan dibedakan dengan dua cara, yaitu dengan cara manual (tenaga manusia) atau mempergunakan alat, seperti mempergunakan sepeda, ban atau mesin khusus. Petani responden di lahan sawah seluruhnya beranggapan memipil jagung menggunakan mesin sangatlah penting dan semua petani responden melaksanakannya. Hal yang beragam terjadi di lahan kering, dimana masih ada petani responden yang memipil mempergunakan tenaga manusia $(3,48 \%)$, mempergunakan sepeda $(0,20 \%)$ dan menggunakan ban/parut $(0,20 \%)$. Sisanya atau pada umumnya (96,20\%) memipil jagung mempergunakan mesin. Alasan memipil dengan mempergunakan mesin dipilih karena lebih efisien dan mengurangi kehilangan hasil, karena biji jagungnya tidak berterbangan (tercecer kemana-mana).

\section{Pengeringan}

Darwis (Potensi Kehilangan Hasil Panen dan Pasca Panen Jagung Di Kabupaten Lampung Selatan) 
DOI: http://dx.doi.org/10.25181/jofsa.v2i1.1054

Journal of Food System and Agribusiness Vol. 2 (1): 55-67

Pengeringan adalah upaya untuk menurunkan kadar air biji jagung agar aman disimpan. Kadar air biji yang aman untuk disimpan berkisar antara 12-14\%. Pada saat jagung dikeringkan terjadi proses penguapan air pada biji karena adanya panas dari media pengering, sehingga uap air akan lepas dari permukaan biji jagung ke ruangan di sekeliling tempat pengering (Brooker et al. 1974).

Pengeringan diperlukan sebelum pemipilan untuk menghindari terjadinya biji pecah. Untuk itu, kadar air biji harus diturunkan menjadi <20\%. Pengeringan dimaksudkan untuk mencapai kadar air biji 12-14\% agar tahan disimpan lama, tidak mudah terserang hama dan terkontaminasi cendawan yang menghasilkan mikotoksin, mempertahankan volume dan bobot bahan sehingga memudahkan penyimpanan (Handerson and Perry 1982).

Apabila pengeringan jagung menggunakan alat pengering, tingkat infeksi cendawan hanya berkisar antara 9-10\%. Oleh sebab itu, pengeringan harus dilakukan secepatnya setelah panen jika cuaca mendukung. Namun bila kondisi cuaca kurang mendukung dan petani tidak mempunyai fasilitas pengeringan maka mutu produk akan rendah.

Prinsip pengeringan dengan cara penjemuran adalah memanfaatkan perpindahan suhu panas sinar matahari ke sekeliling bahan yang dikeringkan. Hal yang perlu diperhatikan dalam penjemuran tongkol atau biji jagung secara langsung di lapang adalah adanya sifat higroskopis bahan, sehingga selama proses pengeringan berlangsung terjadi kenaikan kadar air biji. Kenaikan kadar air biji akan terjadi apabila tekanan uap air jenuh di sekeliling bahan meningkat, karena adanya tekanan osmotik dari jaringan pipa kapiler tanah di bawah tempat penjemuran, atau suhu di lingkungan penjemuran turun pada malam hari.

Cara penjemuran jagung yang umum dilakukan petani adalah: (a) dikeringkan langsung bersama tongkol setelah panen; (b) dikeringkan setelah dirontok atau dipisahkan dari janggel; (c) tongkol dikupas dan dikeringkan terlebih dahulu selama dua hari untuk mencapai kadar air $<20 \%$, dirontok, kemudian dikeringkan lagi; (d) penundaan pengeringan

dan jagung langsung dikarungkan, disimpan 1-2 hari, dipipil dan dijual; (e) tanpa dikeringkan (Dharmaputra et al. 1996, Prastowo et al. 1998).

Beberapa fasilitas penjemuran yang ada di tingkat petani adalah: (a) tanpa alas jemur, bahan langsung dikeringkan di atas tanah atau di tepi jalan aspal, (b) anyaman bambu, (c) lembaran plastik atau terpal, dan (d) lantai jemur. Penjemuran tanpa alas, murah dan mudah dilakukan petani. Tempat penjemuran yang dipilih umumnya di tepi jalan beraspal. Kelemahan cara penjemuran ini adalah mengganggu pengguna jalan dan tercampurnya bahan oleh benda asing (kerikil, tanah atau kotoran) sehingga menurunkan kualitas bahan. Hasil survei terhadap 60 petani responden di Lampung menunjukkan 9,3\% petani menjemur jagung tanpa alas. Di Kediri tidak satu pun petani responden yang menjemur jagung tanpa alas (Dharmaputra et.al. 1996, Prastowo et al. 1998). Menjemur tanpa alas menyebabkan jagung tercampur dengan benda asing sehingga menurunkan harga jual atau memerlukan tambahan biaya untuk memisahkan campuran kotoran (Prastowo et al. 1998).

Darwis (Potensi Kehilangan Hasil Panen dan Pasca Panen Jagung Di Kabupaten Lampung Selatan) 
DOI: http://dx.doi.org/10.25181/jofsa.v2i1.1054

Journal of Food System and Agribusiness Vol. 2 (1): 55-67

Pengeringan dapat dilakukan dengan bantuan alat pengering yang dioperasikan secara mekanis. Beberapa alat pengering mekanis yang banyak dijumpai adalah: (a) alat pengering dengan sumber panas energi bahan bakar minyak (solar, minyak tanah); (b) alat pengering dengan sumber panas energi bahan bakar limbah pertanian; (c) alat pengering dengan sumber panas energi sinar matahari.

Pengeringan jagung pipilan dilakukan antara 2 sampai 3 hari dianggap responden di Kabupaten Lampung Selatan merupakan kegiatan yang penting untuk mempertahankan mutu jagung pipilan yang dihasilkan. Tetapi dalam pelaksanaannya masih sedikit yang mengerjakannya atau dilaksanakan hanya $30 \%$ responden dilahan kering dan 28,64\% di lahan sawah. Kegiatan lainnya dianggap penting tetapi tidak dilaksanakan oleh petani jagung adalah menjemur mempergunakan alas anyaman bambu/plastik. Hal ini terlihat di lahan kering yang tidak ada petani responden yang menjemur mempergunakan plastik atau anyaman bambu. sebaliknya hanya $13,96 \%$ di lahan kering yang menjemur mempergunakan plastik atau anyaman bambu.

Kegiatan lain yang menurut petani dianggap penting dan bisa mempengaruhi mutu dari biji jagung adalah tingginya tumpukan jagung yang dijemur maksimal setinggi $3 \mathrm{~cm}$ dan setiap 2 jam biji jagung yang dijemur dibolak balik. Adapun tujuan dari kegiatan ini agar biji jagung yang dijemur mendapatkan panas yang rata, sehingga kadar air yang ada di biji jagung juga sama. Meskipun petani responden mengetahui, tetapi kegiatan ini tidak banyak yang dilakukan oleh responden. Hal ini disebabkan petani tidak mau repot dan tidak sabar menunggu kering. Sudah menjadi kebiasaan jagung yang dipanen kemudian dijemur dengan mempergunakan alas jemur seadanya dan tidak beberapa lama langsung dijual ke pedagang desa.

\section{Penyimpanan}

Fasilitas penyimpanan sangat diperlukan di sentra produksi jagung yang letaknya jauh dari industri pakan dan pangan. Adanya fasilitas yang memadai akan membantu petani dalam mendapatkan penawaran harga yang lebih baik. Dalam proses penyimpanan, biji jagung masih mengalami proses pernafasan dan menghasilkan karbondioksida, uap air, dan panas (Champ and Highley 1986).

Apabila kondisi ruang simpan tidak terkontrol maka akan terjadi kenaikan konsentrasi air di udara sekitar tempat penyimpanan, sehingga memberikan kondisi ideal bagi pertumbuhan serangga dan cendawan perusak biji. Pengaruh negatif lanjutan dari kenaikan suhu dan konsentrasi uap jenuh udara adalah meningkatnya proses respirasi dengan akibat sampingan makin meningkatnya suhu udara di ruang penyimpanan, yang akan mempercepat proses degradasi biji. Penyimpanan jagung dapat berlangsung lama tanpa menurunkan kualitas biji apabila terjadi keseimbangan kondisi simpan antara kelembaban udara relatif lingkungan dengan kandungan air biji pada kondisi suhu tertentu. Penelitian menunjukkan bahwa pada suhu ruang simpan $28^{\circ} \mathrm{C}$, kelembaban udara nisbi $70 \%$, dan kadar air $14 \%$, biji jagung masih mempunyai daya tumbuh $92 \%$ setelah disimpan selama enam bulan, sedangkan pada suhu simpan $38^{\circ} \mathrm{C}$ daya tumbuh benih menurun menjadi $81 \%$.

Darwis (Potensi Kehilangan Hasil Panen dan Pasca Panen Jagung Di Kabupaten Lampung Selatan) 
DOI: http://dx.doi.org/10.25181/jofsa.v2i1.1054

Journal of Food System and Agribusiness Vol. 2 (1): 55-67

Tabel 2. Nilai Kepentingan Faktor Penentu Kehilangan Hasil Produksi Jagung Pada Lahan Kering dan Lahan Sawah di Kabupaten Lampung Selatan.

\begin{tabular}{ccccc}
\hline & \multicolumn{2}{c}{ Lahan Kering } & \multicolumn{2}{c}{ Lahan Sawah } \\
Faktor Penentu & Nilai & Petani yang & Nilai & Petani yang \\
Produktivitas & Kepentinga & menggunak & Kepenting & menggunak \\
& $\mathrm{n}^{*)}$ & an (\%) & an & an (\%) \\
& & & ${ }^{*}$ & \\
\hline
\end{tabular}

\section{Panen}

- panen tepat waktu (umur jagung 105 hst)

- Dilakukan pemangkasan sebelum pemetikan (5-10 $\mathrm{cm}$ di atas tongkol)

$$
25,24
$$

- Pemetikan 7-10 hari setelah pemangkasan

- Penjemuran jagung tongkol maksimal 10 hari setelah pemetikan selama 3 hari

20,00

5,00

20,00

\section{Pemipilan}

- Pemipilan Manual

1,96

- Pemipilan menggunakan sepeda

$$
1,56
$$

- Pemipilan menggunakan ban/parut

96,20

7,00

100,00

\section{Pengeringan}

- pengeringan jagung pipilan dilakukan selama 2-3 hari

28,64

5,00

30,00

- pengeringan menggunakan alas anyaman bambu/plastik

13,96 5,00

- Ketebalan tumpukan jagung pipilan maksimal $3 \mathrm{~cm}$

$$
17,40
$$

- Selama penjemuran dibalik setiap 2 jam

$$
4,36
$$

24,00

\section{Penyimpanan}

- Penyimpanan jagung tongkol berklobot di

$3,08 \quad 5,54 \quad 3,67$

Darwis (Potensi Kehilangan Hasil Panen dan Pasca Panen Jagung Di Kabupaten Lampung Selatan) 
DOI: http://dx.doi.org/10.25181/jofsa.v2i1.1054

Journal of Food System and Agribusiness Vol. 2 (1): 55-67

para-para

- Penyimpanan jagung

pipilan menggunakan

karung maksimal 2 bulan $\quad 2,68 \quad 3,67 \quad 4,33$

*) 1 =tidak penting; $3=$ agak penting; $5=$ penting; $7=$ sangat penting

Petani responden beranggapan menyimpan jagung tongkol berklobot di para-para bukanlah merupakan kegiatan yang penting. Petani responden yang melakukannyapun tidak banyak, hanya 5,54 \% petani responden di lahan kering yang mengerjakannya. Sebaliknya tidak ada satupun petani responden di lahan sawah yang menyimpan jagung berklobot di para-para. Kegiatan penyimpanan dengan mempergunakan karung dan di simpan maksimal selama 2 bulan, juga tidak anggap penting oleh petani responden di lahan kering. Hanya 3,67 persen responden yang melakukannya. Sebaliknya petani responden di lahan sawah beranggapan menyimpan jagung pipilan dalam karung merupakan kegiatan yang penting dalam menjaga mutu jagung. Meskipun petani responden mengetahui tetapi dalam pelaksanaannya tidak ada satupun petani responden di lahan sawah yang mempraktekkannya. Hal ini bisa terjadi, karena petani sudah terbiasa menjual langsung hasil panen jagungnya, tanpa melakukan. Dan sebagian dari hasil penjualan jagung tersebut di pergunakan untuk modal usaha menanam padi.

\section{KESIMPULAN}

Petani jagung sudah mengetahui pentingnya penanganan panen dan pasca panen dalam menghasilkan produksi jagung yang bermutu. Tetapi dalam pelaksanaan tidak semua petani yang melakukannya. Sementara teknologi untuk kegiatan panen dan pasca panen sudah banyak ditemukan dan dilaksanakan oleh Kementerian Pertanian. Agar dapat meningkatkan pendapatan petani jagung dan sekaligus merubah kebiasaan dalam penanganan panen dan pasca panen, maka kegiatan sosialiasi dan demo pemakaian alat atau teknologi panen dan pasca panen spesifik lokasi di tingkat petani perlu ditingkatkan lagi.

\section{DAFTAR PUSTAKA}

Brooker, D. B., Bakker-Arkema, F. W., \& Hall, C. W. (1992). Drying and storage of grains and oilseeds. Springer Science \& Business Media.

Bokusheva, R., Finger, R., Fischler, M., Berlin, R., Marín, Y., Pérez, F., \& Paiz, F. (2012). Factors determining the adoption and impact of a postharvest storage technology. Food Security, 4(2), 279-293.

Champ, B. R., Highley, E., \& Remenyi, J. V. (1987). Technological change in postharvest handling and transportation of grains in the humid tropics: proceeding

Darwis (Potensi Kehilangan Hasil Panen dan Pasca Panen Jagung Di Kabupaten

Lampung Selatan) 
DOI: http://dx.doi.org/10.25181/jofsa.v2i1.1054

Journal of Food System and Agribusiness Vol. 2 (1): 55-67

of an.. (No. 338.160913 T255t). Canberra, AU: Australian Centre for International Agricultural Research.

Dharmaputra, O. S., Retnowatit, I., Purwadaria, H. K., \& Sidik, M. (1996). Surveys on postharvest handling, Aspergillus flavus infection, and aflatoxin contamination of maize collected from farmers and traders. Mycotoxin contamination in grains, 38 .

Firmansyah, I. U., Saenong, S., Abidin, B., Suarni, Y. S., Tandiabang, J., Wakman, W., ... \& Suwardi, O. K. (2006). Proses pascapanen untuk menunjang perbaikan kualitas produk biji jagung berskala industry dan ekspor. Laporan Akhir. Balai Penelitian Tanaman Serealia, Pusat Penelitian dan Pengembangan Tanaman Pangan. Badan Penelitian dan Pengembangan Pertanian. Depatemen Pertanian, $57 .$.

Fitriani. (2017). Climate Changing Impact on Rice Production. JoFSA, 1(1), 41-46.

Retrieved from http://jurnal.polinela-srv.id/index.php/JOFSA/article/view/82

Handerson, S.M and R.L. Perry. (1982). Agricultural process engineering. Third edition. The AVI Publishing Company Inc., Westport Connecticut.

Kimatu, J. N., McConchie, R., Xie, X., \& Nguluu, S. N. (2012). The significant role of post-harvest management in farm management, aflatoxin mitigation and food security in Sub-Saharan Africa. Greener Journal of Agricultural Sciences, 2(6), 279-288.

Prastowo, B., Sarasutha, I. G. P., Lando, T. M., Zubachtirodin, B. A., \& Anasiru, R. H. (1998). Rekayasa teknologi mekanis untuk budi daya tanaman jagung dan upaya pascapanennya pada lahan tadah hujan. Jurnal Engineering Pertanian, 5(2), 39-62.

Suma, S.D. 2008. Teknologi pascapanen untuk peningkatan mutu jagung. Program Pascasarjana, Fakultas Teknik, Universitas Gadjah Mada, Yogyakarta.

Setyono, A., S. Nugraha, dan Sutrisno. 2008. Prinsip penanganan pascapanen padi. Dalam Padi: Introduksi Teknologi dan Ketahanan Pangan. Buku I. Balai Besar Penelitian Tanaman Padi, Sukamandi.

Tastra, I. K. (1996). Pemipil jagung "SENAPIL", komponen paket supra insus dan pemacu agroindustri dan agribisnis jagung di pedesaan lahan kering. Monograf Balitkabi, (1-1996).

Darwis (Potensi Kehilangan Hasil Panen dan Pasca Panen Jagung Di Kabupaten Lampung Selatan) 